World Lumen Congress 2021 | May 26-30, 2021 |

Iasi, Romania

\title{
The Evaluation of Distance Learning in Tourism Education in the Pandemic Process
}

\author{
Nesrin MENEMENCI BAHÇELERLI
}

https://doi.org/10.18662/wlc2021/42

How to cite: Menemenci Bahçelerli, N. (2021). The Evaluation of Distance Learning in Tourism Education in the Pandemic Process. In A. Sandu (vol. ed.), Lumen Proceedings: Vol. 17 World Lumen Congress 2021 (pp. 426-431). Iasi, Romania: LUMEN Publishing House. https://doi.org/10.18662/wlc2021/42 


\title{
The Evaluation of Distance Learning in Tourism Education in the Pandemic Process
}

\author{
Nesrin MENEMENCI BAHÇELERLI ${ }^{1}$
}

\begin{abstract}
The most important feature that distinguishes the tourism sector from many sectors is that it has a laborintensive structure. Therefore, the knowledge and skills of those working in this sector are important for the competitiveness of businesses. In this direction, tourism education curricula are developed on a practical basis. During the pandemic, the functioning of the tourism industry has come to a complete halt, so education has been moved to digital platforms. In this process, many application-based courses were suspended and these courses were started to be carried out on digital platforms. The aim of this study is to evaluate the views of students who receive tourism education in the pandemic process towards distance learning. The action research technique, one of the qualitative research methods, was used in the study. Action research is a method actively used by educators who take the role of researchers to systematically and scientifically obtain information and develop applications in various fields of education. The sample of the study consists of 24 students studying tourism in the 2020-2021 academic years. The research data were collected using a semistructured interview technique. As a result of the research, while the students expressed positive opinions about distance learning, they stated that they lacked the application aspect, which is a necessity of tourism education. In addition, with the statements put forward, it is concluded that students improve themselves by participating in seminars and trainings with distance learning methods in many different countries in the pandemic process. Among the problems experienced, students stated that there is a lack of infrastructure.
\end{abstract}

Keywords: Tourism, tourism education, distance learning, student, pandemic.

\section{Introduction}

The training and employment of qualified employees is an important issue in the emerging areas of the global business world where fierce competition prevails. In particular, the qualification of the personnel to be employed in the tourism industry; As it ensures the quality and continuity of the service, the knowledge and skills of the employees to be employed in tourism enterprises gain importance (Karatas \& Babur, 2013).

The tourism sector has a dynamic structure that is based on a supplydemand relationship and can show positive or negative reactions to extraordinary

1 Assoc.Prof. Dr., Near East University, Faculty of Tourism, Nicosia, Cyprus, nesrin.menemenci@,neu.edu.tr 
situations that will occur. In global environments, events or destinations that provide a high tourist concentration in the regions where they occur and have a profitable effect in the host countries, and the attractions that make them unique, have a positive effect on the earnings from the tourism sector. Unforeseen and undesirable situations such as epidemics also create negative consequences for the tourism industry, such as changing travel activities, canceling reservations and closing borders globally.

Tourism is one of the industries most affected by the differences that may occur. Tourism, which can also be expressed as a bond that brings people together and unites people, is faced with a situation very different from the crises such as terrorism, war, earthquake experienced in different destinations in the previous periods. Because these crises were experienced throughout certain countries or regions and solutions were found for these crises. However, since the global crisis environment caused by the pandemic is thought and predicted, serious developments have been experienced and results have emerged (Gössling et al., 2020). The pandemic, which created a global impact, deeply affected the tourism industry, interrupted the activities of all parts and stakeholders of the industry.

\subsection{Tourism education and pandemic}

As in all sectors, the pandemic has affected the education sector and faceto-face education has been suspended almost all over the world. In order to ensure the continuity of the existing Covid-19 education system in the world and to ensure the learning of students in all conditions, education systems have switched to distance education applications with their facilities (Strielkowski, 2020).

In the context of tourism education around the world, the main focus is on vocational education. In general, vocational education is the process of enabling individuals in a society to have a profession and to provide the individual with the knowledge, skills and application skills required by the profession, and to develop one's abilities in physical, intellectual, emotional, social and economic aspects. Tourism vocational training is an education that includes various disciplines ranging from theoretical and practical learning to professional ethics and the basic principles of the profession and should be provided for a specific job. The main purpose of vocational tourism education is to provide qualified employees required by tourism.

Tourism education institutions provide both lower level manpower that can provide many services required by tourism enterprises, middle level workforce defined as intermediate manpower, and upper level manpower to train managers, researchers and planners for tourism-related public and private sector institutions. Due to this global epidemic, institutions providing tourism education have also started distance education. Tourism education is carried out within the framework of distance education activities in order to continue the learning processes of students during the education interruption due to the measures taken for coronavirus (Tekin, 2021).

Accordingly, tourism education curricula cannot be implemented on a practical basis. During the pandemic process, the functioning of the tourism 
industry has come to a complete halt, so education has been moved to digital platforms. In this process, many practical-based courses were suspended and these courses started to be carried out on digital platforms. The aim of this study is to evaluate distance learning in tourism education in the direction of students' views during the pandemic process (Seraphin \& Yallop, 2020; Tiwari et al., 2020).

\section{Methodology}

The research was carried out with qualitative research methods. Action research, which is one of the qualitative research techniques, was applied. Action research is a research method that those working in the field of education can use to find solutions to problems specific to their own situation or to ensure their development (Creswell, 2013). The research sample consists of 24 students studying in the tourism faculty of the university in the 2020-2021 academic year. The research data were collected using the semi-structured interview technique developed by the researcher and arranged by taking expert opinion. In the research, interviews were conducted with the participants through online platforms. Participation in the research is on a voluntary basis and coding was done to protect the confidentiality of the participants (S1, S2, etc.). The content analysis method was used in the analysis of the data obtained.

\section{Findings}

Table 1 shows the data obtained in the study. The answers given by the participants to the interview questions were grouped under themes.

Table 1. Opinions of the participants on distance education and tourism education in the pandemic

\begin{tabular}{|c|c|c|}
\hline \multirow{6}{*}{$\begin{array}{l}\text { Definitions } \\
\text { of Distance } \\
\text { Learning }\end{array}$} & Theme & $\begin{array}{l}\text { Number of } \\
\text { views (n) }\end{array}$ \\
\hline & Technology & 18 \\
\hline & No time and place limitation & 15 \\
\hline & Student centered & 11 \\
\hline & Student access to information & 5 \\
\hline & Total & 49 \\
\hline \multirow{3}{*}{$\begin{array}{c}\text { Positive } \\
\text { Effects of } \\
\text { Pandemic } \\
\text { in Tourism } \\
\text { Education }\end{array}$} & $\begin{array}{l}\text { Participation in International Seminars and } \\
\text { certificate programs }\end{array}$ & 11 \\
\hline & Learning how to access information & 7 \\
\hline & $\begin{array}{l}\text { Learning to use the internet and social media for } \\
\text { professional development }\end{array}$ & 6 \\
\hline
\end{tabular}


Nesrin MENEMENCI BAHÇELERLI | Lumen Proceedings 17 | WLC 2021

\begin{tabular}{|c|c|c|}
\hline & Expanding the communication network & 2 \\
\hline & Total & 26 \\
\hline \multirow{6}{*}{$\begin{array}{l}\text { Barriers in } \\
\text { Tourism } \\
\text { Education } \\
\text { Due to the } \\
\text { Pandemic }\end{array}$} & Lack of practical courses & 20 \\
\hline & Inability to do internship & 16 \\
\hline & Infrastructure and technology inadequacy & 10 \\
\hline & Not being able to find a part-time job & 9 \\
\hline & $\begin{array}{l}\text { The feeling of graduating with incomplete } \\
\text { information }\end{array}$ & 3 \\
\hline & Total & 58 \\
\hline
\end{tabular}

Source: Author's own conception

First of all, students were asked to define distance education in the study and their opinions are stated in Table 1. Participants defined distance education as Technology (n18), No time and place limitation (n15), Student centered (n11), Student access to information (n5). The majority of the participants defined distance education as technology-based and not limited by place and time.

"The most important feature of distance education is that we can attend the lesson wherever we want and access the lesson after the lesson." (S3)

"I define distance education as technological education. It is an education in which the courses are conducted on the internet and the student is directed to research." (S11)

Participants revealed that a total of 26 views on the positive effects of the pandemic on tourism education. These; Participation in International Seminars and certificate programs (n11), Learning how to access information (n7), Learning to use the internet and social media for professional development (n6), Expanding the communication network (n2). When the answers given by the participants about the positive effects of the pandemic on tourism education are examined, it is seen that the participants have the opportunity to develop their knowledge, skills and abilities in this direction.

"With distance lectures and more research projects and assignments, we needed to do more research and learned how to find information." (S5)

"Before the pandemic, I used social media mostly to follow my friends. But since we can't go out during the pandemic and we have more time, I started to follow the pages for tourism. I attended the online seminars organized. I met foreign people." (S17)

In addition, it was asked what are the barriers in tourism education due to the pandemic. Lack of practical courses (n20), Inability to do internship (n16), Infrastructure and technology inadequacy (n10), Not being able to find a part-time job (n9), The feeling of graduating with incomplete information (n3) are barriers 
which stated by participants. It has been concluded that the most important barrier in tourism education during the pandemic process is the inability to conduct applied courses. When the answers of the participants are examined, it is seen that the application, not being able to find a job and the lack of internship are the biggest problems in tourism education in this process.

\section{Conclusion}

As a result of the research, students' views on distance education during the pandemic process were evaluated. Students were primarily asked to define distance education. Students defined distance education as technology-based, studentcentered, lack of time and place limitations, and learning from which the student reaches the information. When asked to evaluate the opportunities and positive effects of distance learning during the pandemic process, most of the students stated that they had the opportunity for professional development and participated in international seminars and certificate programs. When asked about the barriers that occur in tourism education with the effect of the pandemic, the students stated that they experienced shortcomings in practical-based courses and could not find internship opportunities.

Tourism education has to be carried out as a whole, complementing each other on a theory and practice basis. Because the tourism sector has a dynamic structure and the education provided in this field should also have a dynamic structure. So, the training given should not be just theoretical. However, it has become impossible to provide practical training due to the global epidemic experienced. This is supported by the results obtained. In this context, in order to ensure the sustainability of qualified human resources in tourism, students who receive tourism education should be supported with their theoretical knowledge with practice-based trainings intensified with the reduction of the impact of the pandemic. After the recruitment process of tourism students who graduate in this process, their practical knowledge should be supported with orientation programs.

\section{References}

Creswell, J. W. (2013). Qualitative inquiry and research design: Choosing among five approaches (3rd ed.). Sage.

Gössling, S., Scott, D. \& Hall, C. M. (2020). Pandemics, Tourism and Global Change: A Rapid Assessment of Covid-19. Journal of Sustainable Tourism, 29(1), 1-20. https://doi.org/10.1080/09669582.2020.1758708

Karataş, M. \& Babur, S. (2020). Gelişen Dünya'daTurizm Sektörünün Yeri [The Place of the Tourism Sector in the Developing World]. KMÜ Sosyal ve Ekonomike Arasstırmalar Dergisi [KMU Journal of Social and Economic Studies], 15(25), 15-24. https://dergipark.org.tr/tr/download/article-file/107229

Seraphin, H., Bah, M., Fyall, A., \&Gowreesunkar, V. (2021). Tourism education in france and sustain-able development goal 4 (Quality Education). Worldwide Hospitality and Tourism Themes, 13(1), 139-147. https://doi.org/10.1108/WHATT-08-2020-0083 
Nesrin MENEMENCI BAHÇELERLI | Lumen Proceedings 17 | WLC 2021

Strielkowski, W. (2020). International Tourism and Covid-19 Recovery Strategies for Tourism Organisations. Preprints, 1-6.

https://doi.org/10.20944/preprints202003.0445.v1

Tekin, Y. (2021). Innovative Practices in Tourism Sector and Tourism Education in The Process of Covid-19. Journal of Social, Humanities and Administrative Sciences, 4(9), 876888. https://doi.org/10.26677/TR1010.2021.804

Tiwari, P., Seraphin, H. \& Chowdhary, N. R. (2020). Impacts of COVID-19 on tourism education: analysis and perspectives. Journal of Teaching in Travel \&Tourism, 1-27. https://doi.org/10.1080/15313220.2020.1850392 